\title{
Preliminary Study of Various Intervals and Administration of Feed Enriched with Turmeric and Garlic on the Growth Performance of Catfish
}

\author{
Fajar Basuki ${ }^{1, *}, T$ Yuniarti $^{1}$, Ristiawan $\mathrm{AN}^{1}$, and Sri Hastuti ${ }^{1}$. \\ ${ }^{1}$ Aquaculture Department, Faculty of Fisheries and Marine Science Faculty, Diponegoro University, \\ Indonesia.
}

\begin{abstract}
As a food ingredient, turmeric curcumin increases appetite and increases the effectiveness of digestive organs function, while garlic increases fish growth. The combination of the two ingredients is believed to increase growth and survival rate of catfish. This study aimed to determine growth performance, Food Conversion Ratio (FCR) and Survival Rate (SR) of catfish seeds in high density fish farming based on biofloc, and supplemented with turmeric and garlic for feed. The research methodology was a complete randomized design, and treated with $\mathrm{T} 1$ : turmeric and garlic given once a week; T2: turmeric and garlic were given twice a week, and T3: turmeric and garlic were given three times a week. Fish weight was recorded every week, then data were analyzed for fish growth using regression. The study was conducted in 4 weeks. The results showed that the best weight growth performance was obtained at $\mathrm{T} 1$ with the regression equation YT1 $=-1.07+17.92$. This equation provides predictions that fish harvesting can be carried out within 6 weeks, with the average weight of fish measured at 100 grams and $\mathrm{FCR}=0.91 \pm 0.016$ and $\mathrm{SR}=88.45 \pm 8.89 \%$.
\end{abstract}

\section{Introduction}

Catfish Clarias gariepinus is one of the most popular fish for farmers because it is easy to be cultivated in limited site and water. Catfish is affordable sources of protein and well-known among society. In general, a kilogram of fresh catfish costs 25.000,00 IDR. In 2013, production of catfish in Central Java was recorded 75.236 tons [1] while according to [2] the production of catfish in 2016 slightly increased to $122.292,16$ tons $(62.54 \%)$. Production of catfish can be carried out in ponds, paddy-field ponds, and recently, catfish can be cultivated in tarpaulin pond in a biofloc system under high-density cultivation. [3].

The main problem of cultivating catfish in biofloc system under high-density cultivation is high mortality rate due to various diseases. Some researchers have suggested causes of various diseases in catfish, such as Edwardsiella ictaluri that has been observed as the cause of Enteric Septicemia of Catfish (ESC). According to [4], the bacteria transmit a disease to Clarias sp causing them to swim vertically and give slow responses to feed, experience peritonitis and hemorrhagic dermatitis. According to [5] the first Epizootic was observed in yellow catfish Pelteobagrus fulvidraco which was caused by E. ictaluri, signed by skin

*Corresponding author: fajar.basuki@live.undip.ac.id 
bleeding, ulceration and inflammation of the intestine, while in chronic case, the symptom was fluctuated red swelling in head dorsum.

The next pathogen causing disease [6] are protozoan Ichthyophthirius multifiliis Fouquet (Ich) and Aeromonas hydrophila bacteria which are known as two main pathogens of cultivated fish causing high mortality rate. The research on Catfish showed that the combination of two pathogens results in $80 \%$ mortality rate. The infection caused by $A$. hydrophila has contributed to $22 \%$ mortality rate, while I.. multifiliis Fouquet (Ich) has contributed to $35 \%$ mortality rate. According to [7], Flavobacterium columnare and E. ictaluri are two main pathogens that threaten global catfish cultivation.

No proper medication to cure the diseases affecting catfish in tarpaulin pond in biofloc system under high-density cultivation putting the farmers at risk of having big loss. As noted above, pathogenic bacteria contribute to the mortality rate of catfish in aquaculture ponds. Preventive techniques are needed to prevent pathogenic bacteria from appearing in aquaculture ponds. In addition to maintain water quality, feed enriched with antibacterial substances could be important. This research focused on garlic and turmeric for feed enrichment to support growth performance and high survival rate. As bacteria contribute to the high mortality rate of catfish in aquaculture. A curative technique is needed to prevent pathogen bacteria from appearing in cultivation pond. Besides maintaining water quality, feed enriched by antibacterial substances is important.

Garlic is a common and popular spice and used throughout history to prevent and treat many different diseases such as aches, deafness, diarrhea, constipation, tumors, and respiratory problems [8]. Garlic aqueous extract has antibacterial properties against Streptococcus aureus present in hamburger. Moreover, garlic aqueous extract can be used not only as a flavor but also as a natural additive for hamburger. In addition, garlic has antibacterial properties against other Gram-positive and Gram-negative bacteria [9]. Ethiopian garlic is used in traditional medicine for infectious disease and some other cases. This research suggests that garlic A. sativum has antimicrobial properties against S.aureus [10].

Turmeric Curcuma aromatica are used in combination with astringents and aromatics for bruises, sprain, hiccough, bronchitis, cough, leucoderma and skin eruptions, also used to neutralize snake venom [11]. Moreover, it has been presented that [12] curcumin may have potential as a therapeutic agent in diseases such as inflammatory bowel disease, pancreatitis, arthritis, and chronic anterior uveitis, as well as certain types of cancer.

The aim of the research was to measure ideal interval of administration of feed enriched with turmeric and garlic to maintain growth performance, health and high survival rate.

\section{Materials and Methods}

Catfish as the experimental fish weighed $21.65 \pm 1.09 \mathrm{~g} / \mathrm{fish}$ was cultured at a density of 1.100 fishes $/ \mathrm{m}^{3}[3]$. The treatments were T1: enriched feed given once a week; T2: enriched feed given twice a week and T3: enriched feed given three times a week. Preparation of Garlic and Turmeric: $15 \mathrm{~g}$ of garlic and $15 \mathrm{~g}$ of turmeric were blended and added to $1 \mathrm{~kg}$ of feed. The additional percentage of garlic/tumeric used in the experiment was 3\% (13).

Tarpaulin pond with $3 \mathrm{~m}$ diameter was used for the experiment and equipped with $6 \mathrm{~mm}$ iron frame. Total volume of water for each pond was 3,000 L. Fish are fed with commercial floating feed contains $31-33 \%$ of protein; $3-5 \%$ of fat; $4-6 \%$ of fiber, $10-13 \%$ of ash, and 11$13 \%$ of water. For every kilogram of feed, $5 \mathrm{cc}$ of commercial probiotics diluted in $150 \mathrm{cc}$ of water was added. The commercial probiotic contained Lactobacillus casei and Saccharomyces cerevisiae according to the ingredients information. 
Prior to fish seedling, clean water was filled into the tank reaching the water depth of 43 $\mathrm{cm}$ or $\pm 3 \mathrm{~m}^{3}$, added with $600 \mathrm{~g}$ of $\mathrm{NaCl} / \mathrm{tank}$ or $200 \mathrm{gram} / \mathrm{m}^{3}, 300 \mathrm{cc}$ of molasses $/$ tank or $100 \mathrm{cc} / \mathrm{m}^{3}$ and $5 \mathrm{cc}$ of commercial probiotics [14]. The water recirculation was carried out by 3 water pumps/tank.

Completely randomized design was used in the experiment. Catfish was reared into the tank randomly based on the density for each treatment which was $1.100 / \mathrm{m}^{3}$ or 3.300 seed/tank. Then data were analysed for fish growth using regression analysis.

Individual growth rate was measured once a week during the rearing period (4 weeks). Regression analysis was conducted by using SPSS 2.0. Survival Rate (SR) was calculated by dividing the number of fish at the end of the period by the number of fish at the beginning of the period, multiplied by $100 \%$ [15]. Food Conversion Ratio (FCR) was calculated by comparing total feed weight $(\mathrm{g})$ to total fish weight $(\mathrm{g})$ [16]

\section{$3 \quad$ Results and Discussion}

\subsection{Result}

\subsubsection{Growth Performance}

After the administration of fish feed enriched with garlic and turmeric, the growth of the fish was observed (Figure 1). At the beginning of week 1, the fastest growth were observed in T2 with average absolute weight 35.83 gram, followed by T1 with 30.21 gram and T3 with 26.71 gram. The growth performance in the second week showed that the increase of absolute weight of T1 was 44.73 gram which just behind the weight of T2 with 44.82 gram, while T3 was only measured at 36.58 gram. The observation in the following weeks until the end of the period showed that $\mathrm{T} 1$ had the highest growth performance.

The result of regression analysis shows that weight growth performance for $\mathrm{T} 1 \mathrm{can}$ be presented using the equation $\mathrm{Y}_{\mathrm{T} 1}=-1.07+17.92 \mathrm{X}$, while treatment $\mathrm{T} 2$ is presented in equation $\mathrm{Y}_{\mathrm{T} 2}=5.98+14.62 \mathrm{X}$, and treatment $\mathrm{T} 3$ is presented in $\mathrm{Y}_{\mathrm{T} 3}=1.44+13.44 \mathrm{X}$. From those equations, if the expected fish weight is 100 grams, T1 needs 6 weeks, T2 needs 7 weeks, while T3 needs 8 weeks.

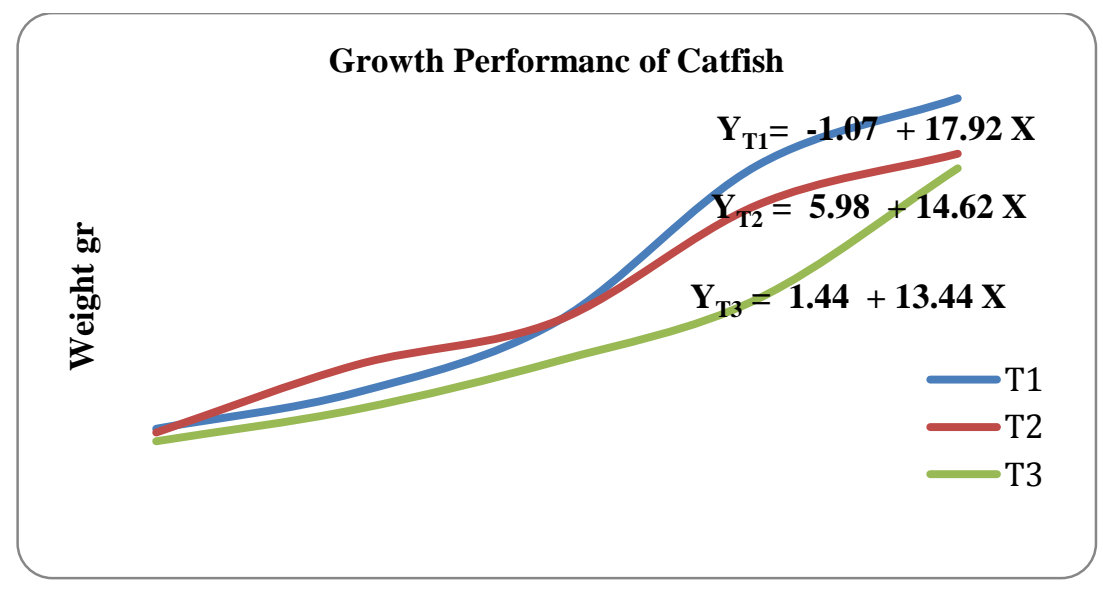

Fig 1. Growth performance in various feeding intervals 


\subsubsection{FCR (food conversion ratio)}

Every week, observation was conducted on fish growth and quantity of feed. In Week 4, total quantity of feed was measured and compared to the fish growth. The comparison is presented in Figure 2. FCR of T1 was $0.91 \pm \mathbf{0 . 0 1 6}$ which means that $0.91 \mathrm{~kg}$ of feed resulted in $1 \mathrm{~kg}$ of catfish biomass. In T2 and T3, the FCR increased to be $0.92 \pm 0.022$ and $0.93 \pm 0.014$, respectively. From the observation, fish that were given feed enriched with garlic and turmeric showed significant decrease of FCR.

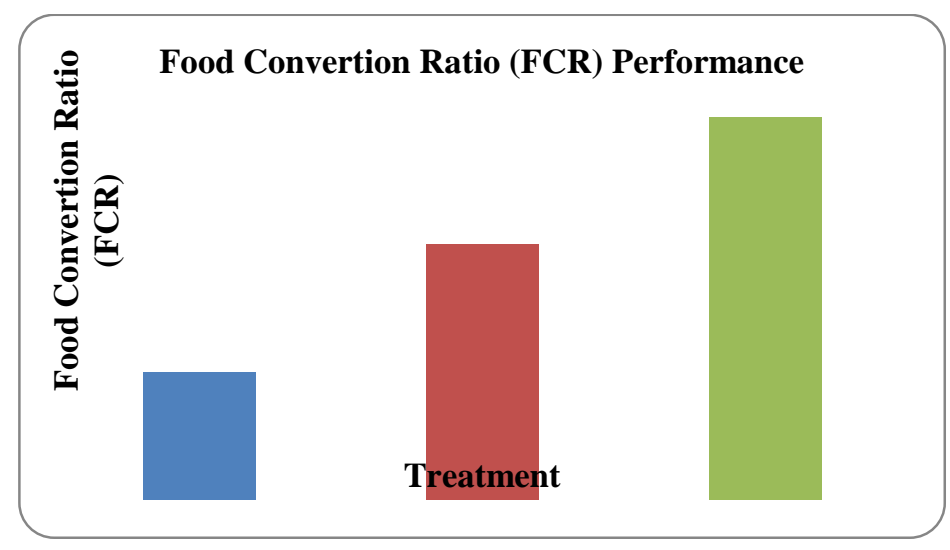

Fig 2. Food Conversion Ratio (FCR) of catfish fed with diet supplemented with garlic and turmeric at various feeding intervals

\subsubsection{SR (Survival Rate)}

The survival rate (SR) is presented in figure 3. $\mathrm{SR}$ of $\mathrm{T}_{1}$ was $88.45 \pm 8.89 \%, \mathrm{~T}_{2}$ was $88.54 \pm 9.04 \%$, while $\mathrm{T}_{3}$ was $79.25 \pm 9.04 \%$ or a noticeable decrease compared to $\mathrm{T}_{1}$.

From the field observation, cannibalism appears to be the cause of mortality. The smaller fish were eaten by the bigger one, and wounded fish were attacked by healthy fish causing highest mortality rate in $\mathrm{T} 3$.

\subsection{Discussion}

\subsubsection{Growth Performance}

In line with statement from [3], using the density of 1,100 fish/m3 or 3,300 fish/tank, fish growth was noticeable. Yet, after the administration of feed enriched with garlic and turmeric for one week, the fish grew in different growth rate. In week 1, T2 had the fastest growth compared to T1 and T3, yet in week 2, T1 grew faster than T2 and T3. For the following weeks, $\mathrm{T} 1$ showed better growth performance compared to T2 and T3. It is assumed that the administration of feed enriched with garlic and turmeric contributes to positive growth performance of catfish.

Turmeric is a natural product containing curcuminoids. Curcuminoids are phenolic substances which are commonly used as spices, pigments and additives as well as therapeutic agents in some foods [17]. Several studies using the modern techniques have authenticated 
turmeric used as antimicrobial, anti-inflammatory, anti-fertility, anticancer, anti-diabetic, antioxidant, hypolipidemic, anti-venom, anti-hepatotoxic, nephroprotective, anticoagulant, etc.[18]. As a food ingredient, curcumin increases appetite and improves the effectiveness of the digestive organs, stimulates the bile wall and stimulates the release of pancreatic enzymes, such as amylase, lipase and protease to improve the digestion of carbohydrates, fats and proteins.

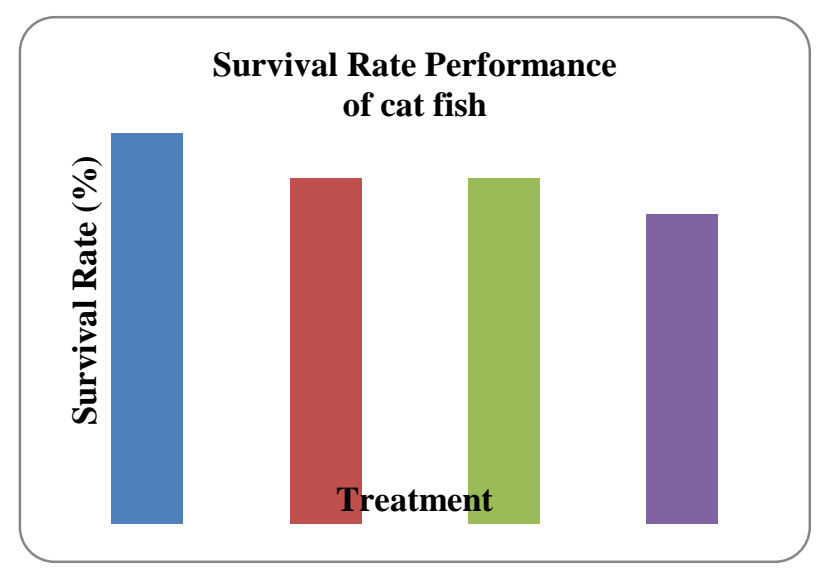

Fig 3. SR (Survival Rate) of catfish fed with diet supplemented with garlic and turmeric at various feeding intervals

A growth rate decreased in T2 and T3 was assumed as a result of turmeric administration. According to [19] turmeric administration in Broiler (Gallus sp) [20] contributes the suppression of intracellular level in the release of prolactin and $\mathrm{GH}$, as well as inhibits proliferation of pituitary tumor cells, induces apoptosis, and decreases hormone production.

The research showed that all fish grew well as a result of garlic and turmeric administration. Garlic and onion are included in Liliaceae, also known as Allium sativum dan Allium cepa. The word Allium is derived from all in Celtic, which means spicy. Garlic and onion are believed from Middle East and have been part of traditional medication [21]. Allium sativum has had an important dietary and medicinal role for centuries [10].

Garlic extract improves growth and feed utilization of juvenile starlet sturgeons [22]. Laboratorial investigations show that garlic juice diluted to one part in 125,000 inhibits the growth of bacteria of the genera Staphylococcus, Streptococcus, Vibrio (including $V$. cholerae) and Bacillus (including B. ryphosus, B. dysenteriaea and B. enteritidis), moreover, garlic juice exhibits a broad spectrum of activity against zoo pathogenic fungi and many strains of yeast, including some that cause vaginitis [20] traditional medicine for its wide variety of therapeutic properties, especially its potent antimicrobial effects[23]. On the other hand, weight reduction of $\mathrm{T} 2$ and $\mathrm{T} 2$ is thought to be a result of excessive garlic administration.

\subsubsection{FCR (food conversion ratio).}

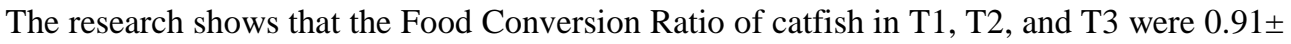
0.016 (T1), $0.92 \pm 0.022$ (T2), and $0.93 \pm 0.014$ (T3) which were higher than the previous report [14] showing that the FCRs of catfish cultivation in a biofloc system under high-density cultivation are 0.45 to 0.81 . 
While according to [13] $1 \mathrm{~kg}$ of feed containing 3\% of garlic increases FCR in monosex Tilapia zillii. Feeding monosex T. zillii without garlic enrichment has resulted FCR of 1.76 while feeding with garlic enrichment has resulted FCR of 1.02. Similar result was obtained in rainbow trout Oncorhynchus mykiss. Garlic enrichment in feeding O. mykiss has increased FCR from 2.3 (without garlic) to 1.1 by using $1 \mathrm{~g}$ of garlic in $100 \mathrm{~g}$ of feed [24].

\subsubsection{SR (Survival Rate)}

The result showed that the $\mathrm{SR}$ of catfish in $\mathrm{T}_{1}$ was $88,45 \%, \mathrm{~T}_{2}$ was $88.54 \%$ or an insignificant increase, while in $\mathrm{T}_{3}$ was $79,25 \%$. The $\mathrm{SR}$ of catfish in $\mathrm{T}_{1}$ and $\mathrm{T}_{2}$ was in line with the research conducted by [14] which states that the SRs of catfish cultivation in biofloc system reaches $85.8 \%$ to $91.4 \%$, while SR of catfish in $\mathrm{T}_{3}$ was lower. In a research conducted by [13], the addition of $3 \%$ garlic to $1 \mathrm{~kg}$ of feed to monosex T. zillii increased SR to $100 \%$. Garlic improves the resistance of the fish against pathogen bacteria, which in line with [25] that Diallyl thiosulfinate (allicin) is the agent found in garlic which is responsible for the antibacterial and antifungal activity of this plant extracts.

\section{Conclusion}

Catfish administered with garlic and tumeric once a week provide better growth performance based on the equation $\mathrm{Y}_{\mathrm{T} 1}=-1.07+17.92 \mathrm{X}$. The equation provides a prediction that fish harvesting can be conducted within 6 weeks, with an average weight of fish measured at 100 $\mathrm{g}$ and $\mathrm{FCR}=0.91 \pm 0.016$ as well as $\mathrm{SR}=88,45 \% \pm 8.89 \%$.

\section{Acknowledgements}

The researcher expressed his gratitude to the Dean of the Faculty of Fisheries and Marine Sciences of Diponegoro University for permission to use the Catfish Teaching Factory facility for a series of research on Catfish Hatchery Technology Innovation.

\section{Reference}

1. Indonesian Director General of Aquaculture. Series of Data Statistics of Aquaculture in Indonesia (2013).

2. Central Java Department of Marine and Fisheries. Data on aquaculture statistics (main commodity production in 2016).

3. F. Basuki, T. Yuniarti, D. Harwanto, T. Susilowati. IOP Conference Series: Earth and Environmental Science, 116 (2017).

4. A. D. Koswara. Graduate School of Bogor Agricultural University (2009).

5. S.Ye, H. Li, G. Qiao, Z. Li. Aquaculture 292: 6-10 (2009).

6. Xu, De-Hai, Julia W. Pridgeon, Phillip H. Klesius, Craig A. Shoemaker. 2009. J.vetpar. 184 101- 107(2012).

7. H.T. Dong, V.V.Nguyen, K. Phiwsaiya , W. Gangnonngiw, B. Withyachumnarnkul, C. Rodkhum, S. Senapin. Aquaculture 448: 142-150 (2015).

8. A. Marchese, R. Barbieri, A. Sanches-Silva, M. Daglia, S.F. Nabavi, N.J. Jafari, M.Izadi, M. Ajami, S.M. Nabavi, TIFS. 52 49-56 (2016) 
9. A. S.Mozaffari Nejad, S. Shabani, M. Bayat, E. H. Seyed. Jundishapur J Microbiol. 2014 November; 7(9)

10. D. Daka. AJB09. 553. 104 (2011)

11. A. Sikha, A. Harini, L. Hegde Prakash L. Journal of Pharmacognosy and Phytochemistry 2015; 3(5): 01-04 (2015)

12. J. S. Jurenka, Julie S. Altern Med Rev. Jun; 14(2):141-53. (2009).

13. O.O. Ajiboye, A.F. Yakubu, 11 1J.O. Simpa and 2S.A. Balogun. wjfms. 8 (2): 115-122 (2016)

14. F. Hapsari. AACL Bioflux 9(2):334-339 (2016)

15. M.W. Yusuf, N.B.P. Utomo, M. Yuhana dan Widanarni, J. Fish. Aquat. Sci., 10 (6): 523-532 (2015)

16. M. Z. Islam, Md.R.I. Sarder and Md. R.I. Akhand. IJFAS 2(3): 186-191 (2015)

17. A. Amalraj, A. Pius, S. Gopi, S.Gopi, S. j.jtcme.7: 205-233(2017).

18. S.Yadav. R. Khar. M. Mujeeb. M. Akhtar, \& D. Yadav, D. Int J Green Pharm. 7:85 (2013)

19. H. Pratikno. ANATOMI FISIOLOGI, XVIII (2). pp. 39-46. ISSN 0854-5367

20. M. Miller, S. Chen, J. Woodliff, and S. Kansra. Endocrinology. 149 (8): 4158-4167 (2008)

21. E. Block. scientificamerican. 252. 3 (1985)

22. D. H. Lee, C. S. Ra, Y. H. Song, K. I. Sung, \& J. D. Kim, J. D. Asian-Aust. J. Anim. Sci. Vol. 25, No. 4: 577 - 583 (2012)

23. A. Marchese. R. Barbieri, A. Sanches-Silva, M. Daglia, S.F. Nabavi, N.J. Jafari, M. MortezaIzadi, M. Ajami, S.M. Nabavi. Trends in Food Science \& Technology. 52:4956 (2016).

24. E.J. Nya, and B. Austin. Journal of Fish Diseases. 32(11): 963-970 (2009)

25. R.S. Feldberg, S.C. Chang, S, A.N. Kotik, M. Nadler, Z. Neuwirth, D.C. Sundstrom, and N.H. Thompson. Antimicrobial Agents and Chemotherapy, 32(12): 1763-1768 (1988). 